\title{
ДО ДЕЯКИХ ПИТАНЬ ЗАБЕЗПЕЧЕННЯ КОНСТИТУЦИЙНИХ ГАРАНТІЙ ПРАВ І СВОБОД ЛЮДИНИ І ГРОМАДЯНИНА В УКРАЇНІ
}

\author{
КОТЬКО Марія Ігорівна - студентка 2 курсу 6 групи факультету Інституту \\ підготовки кадрів для органів юстиції України Національного юридичного \\ університету імені Ярослава Мудрого \\ ORCID ID: https://orcid.org/0000-0002-1460-2200 \\ УДК 340.132 \\ DOI 10.32782/LAW.UA.2021.4.4
}

\begin{abstract}
Конституційні гарантї прав і свобод людини і громадянина мають велике значення в забезпечені реалізації інтересів громадян у демократичній краӥні. У статті досліджено, які існують основоположні конституиійні гарантї. Відповідність гарантій, які встановлено в Україні, міжнародним стандартам. Проведено аналіз забезпечення ебективної реалізачиї зазначених гарантій в Украӥні. Виявлено основні прогалини в забезпеченні реалізачій гарантї. Запропоновано шляхи та механізми вдосконалення украӥнсъкого законодавства для вирішення проблеми реалізащї конститущійних гарантій.

Ключові слова: конституційні гарантї, забезпечення реалізачій, обмеження прав $i$ свобод, ефективність гарантій, Конституиія Украӥни, судова практика, судовий розгляд, виконання рішень.
\end{abstract}

Постановка проблеми

На сьогодні проблема забезпечення реалізації конституційних гарантій прав і свобод людини і громадянина в Україні стає все більше актуальною, бо це впливає на обмеження та звуження основоположних прав людини. Хоча в законодавстві і закріплені основні гарантії, проте на практиці існують проблеми з їх реалізації.

\section{Мета статті}

Головною метою роботи $є$ встановлення основних гарантій, які знайшли своє закріплення в сучасному українському законодавстві, та їх відповідності міжнародним стандартам, виявлення основних проблем ïx реалізації. А також внесення пропозиції щодо ефективного вирішення проблеми із забезпечення конституційних гарантій прав і свобод людини і громадянина в Україні.

Аналіз останніх досліджень і публікацій

Питанням гарантій конституційних прав і свобод громадян приділяли увагу такі українські вчені-конституціоналісти, як: В. В. Букач, А. В. Грабильніков, I. В. Дробуш, М. В. Зайцева, О. І. Кононенко, А. Д. Воєводін, А. Ю. Олійник, В. А. Патюлін, О. В. Пушкіна, П. М. Рабінович, І. В. Ростовщиков, В. Я. Тацій, Ю. М. Тодика, В. ‥ Федоренко та інші.

Виклад основного матеріалу

Теорія суспільного договору Джона локка зіграла важливу роль у формуванні сучасних західноєвропейських демократичних державах. Він вважав, що люди вільні та рівні від народження та мають невід'ємні природні права, але водночас розумів стан війни всіх проти всіх, коли люди вступають у конфлікт між собою, з метою реалізації та захисту власних прав. Тому для подолання природного стану конфлікту було сформовано систему врядування, яка повинна забезпечити отримання певних благ та їх захист. «Отже, політичною владою я вважаю право створювати закони, які передбачають смертну кару i, відповідно, усі інші менш суворі засоби покарання для регулювання й 


\section{Теорія, історія держави і права, конституційне право}

збереження власності, і застосовувати силу співтовариства для виконання цих законів i для захисту держави від нападу ззовні і все це тільки заради суспільного блага» [1]. Гарантіями існування такої системи виступала можливість повалення такої системи навіть iз застосуванням сили, якщо це необхідно у випадку, коли органи влади не виконують обов'язки із забезпечення захисту прав.

3 розвитком сучасного конституціоналізму саме конституція стала фундаментом правової системи держави, ії законодавства, а також визначальним чинником забезпечення прав і свобод людини, їх захист, охорони державного суверенітету, становлення громадянського суспільства, формування та розвитку інститутів державної влади. Тому постало питання конституційного закріплення основних прав людини з урахуванням людських можливостей та державних дій, що викликало потребу в конституційному унормуванні природних прав.

Україна є країною, у якій державно-правовий розвиток спрямований на побудову демократичної, правової, соціальної держави, яка, у свою чергу, могла б бути здатною втілити конституційні принципи визнання людини найвищою соціальною цінністю, чиї права, свободи і інтереси визначають шлях діяльності державної влади. Тож у конституційному праві визначається основне коло найбільш важливих питань реалізації Конституції України з метою ефективного забезпечення прав i свобод людини і громадянина.

Під гарантіями прав і свобод людини і громадянина традиційно розуміється система загальних (політичних, економічних, духовних та ін.) і спеціально-юридичних засобів та інститутів, спрямованих на створення умов для реалізації прав людини, а також забезпечення їх всебічної охорони та захисту від порушень [2]. Система гарантій прав людини уявляється наступним чином: група загальних («матеріальних») гарантій, група спеціальних (юридичних) гарантій, організаційні гарантії [3]. Загальні гарантії - це об'єктивні матеріальні й духовні умови реалізації основних прав і законних інтересів людини (економічні, політичні, соціальні та духовні). Варто зазначити,соціальні гарантії передбачають насамперед наявність державних соціальних програм, пов'язаних із задоволенням тих необхідних інтересів, які людина не може здійснювати самостійно, без допомоги держави (освіта, охорона здоров' я, соціальне забезпечення [4].

Проте обсяг прав і свобод не є абсолютним. Так, випадки обмеження прав чітко встановлені законом, а саме: у ст. 64 Конституції України зазначено, що Конституційні права і свободи людини і громадянина не можуть бути обмежені, крім випадків, передбачених Конституцією України. В умовах воєнного або надзвичайного стану можуть встановлюватися окремі обмеження прав і свобод із зазначенням строку дії цих обмежень. Не можуть бути обмежені права і свободи, передбачені статями 24, 25, 27, 28,29, 40, 47, 51, 52, 55, 56, 57, 58, 59, 60, 61,62, 63 цієї Конституції [5].

Згідно із Законом України «Про правовий режим надзвичайного стану» від 16.03.2000 р. Передбачається можливість тимчасового введення надзвичайного стану в Україні чи в окремих їі місцевостях при виникненні надзвичайних ситуацій природного характеру, що призвели чи можуть призвести до людських та матеріальних втрат, створюють загрозу життю і здоров'ю громадян, також п. 1 ч. 2 ст. 4 встановлює, що надзвичайний стан може водитися в разі пандемії, що створює загрозу життю і здоров’ю значних верств населення,а також допускається тимчасове, зумовлене загрозою, обмеження у здійсненні конституційних прав i свобод людини і громадянина та прав і законних інтересів юридичних осіб [6].

Щодо процедури введення надзвичайного стану, то вона передбачена в ч. 3 ст. 83, п. 31 ч. 1 ст. 85, п. 21 ч. 1 ст. 106 Конституції України та в ст. 5 Закону України «Про правовий режим надзвичайного стану», так надзвичайний стан в Україні або в окремих іiі місцевостях вводиться Указом Президента України, який підлягає затвердженню Верховною Радою України протягом двох днів з моменту звернення Президента України. Пропозиції щодо введення надзвичайного стану 3 підстав пандемії, інших особливо тяжких надзвичайних ситуацій природного характеру подає Кабінет Міністрів України [5]. Також законодавцем встановлено терміни введен- 
ня надзвичайного стану, а саме, надзвичайний стан в Україні може бути введено на строк не більш як 30 діб і не більш як 60 діб в окремих iï місцевостях, а у разі необхідності - може бути продовжений Президентом України, але не більш як на 30 діб. Новий Указ Президента України про продовження дії надзвичайного стану набирає чинності після його затвердження Верховною Радою України.

Проте, незважаючи на те, що Конституцією чітко встановлені права і свободи людини та громадянина, в Україні спостерігається тенденція спроб різного тлумачення окремих положень Конституції, які саме гарантують забезпечення та захист таких прав. Так, наприклад, виникають суперечки $з$ приводу тлумачення окремих положень таких статей Конституції, як «право на охорону здоров'я, медичну допомогу та медичне страхування» (стаття 49), «право на достатній життєвий рівень для себе і своєї сім'ї, що включає достатнє харчування, одяг, житло (стаття 48), а також інші позитивні права, які в сучасних українських умовах перетворилися для значної кількості громадян на справжню фікцію.

Наприклад, право кожного на охорону здоров'я, яке закріплено в ст. 49 Конституції, передбачає, що у державних і комунальних закладах охорони здоров'я медична допомога надається безоплатно. Тлумачення положення цієї статті надає КСУ у рішенні у справі за конституційним поданням 53 народних депутатів України щодо офіційного тлумачення положення частини третьої статті 49 Конституції України «у державних і комунальних закладах охорони здоров'я медична допомога надається безоплатно» (справа про безоплатну медичну допомогу), у якому народні депутати звернулися 3 клопотанням щодо офіційного тлумачення терміна «безоплатність медичної допомоги» та роз'яснення чи слід розуміти норму Конституції «таким чином, що медична допомога в державних і комунальних закладах охорони здоров'я може забезпечуватися не тільки за рахунок державного бюджетного фінансування та внесків роботодавців, але й за рахунок залучення коштів населення через інші солідарні форми, такі як лікарняні каси, кредитні спілки тощо» [7]. Так,
КСУ дійшов висновків, що термін «медична допомога надається безоплатно» означає, що індивід, який отримує таку допомогу у державних і комунальних закладах охорони здоров'я, не повинен відшкодовувати іï вартість ні у вигляді будь-яких платежів, ні у будь-якій формі незалежно від часу надання медичної допомоги [7]. Aле в цьому ж рішенні КСУ створює лазівку, так як, на думку КСУ, це положення не забороняє і можливості надання громадянам медичних послуг, які виходять за межі медичної допомоги, за окрему плату. Перелік таких платних послуг не може виходити за межі безоплатної медичної допомоги і відповідно до вимог п. 6 частини першої ст. 92 Конституції України має встановлюватись законом.

Слід зазначити, що на цей момент у Верховній Раді України вже знаходиться проєкт закону щодо державних фінансових гарантій надання медичних послуг та лікарських засобів, в якому пропонується введення механізмів співоплати за медичні послуги, які передбачають, що оплата частково здійснюється державою, а частково громадянином. Аналіз даного законопроекту призводить до повернення до дискусії щодо розуміння та змістовного наповнення понять «медична допомога» та «медичні послуги». У свою чергу, Закон України «Основи законодавства України про охорону здоров'я» у ст. 8 визначає види безоплатної медичної допомоги, а саме: екстрена медична допомога, первинна медична допомога, вторинна медична допомога, третинна медична допомога, паліативна допомога [8]. Виходячи 3 аналізу цього законопроєкту, можна дійти висновку, що в ньому відбувається підміна таких понять, як «медична допомога» на «медична послуга» [9], бо коли в ньому йдеться про медичні послуги, то de facto говорять про медичну допомогу. А це є звуження змісту та обсягу чинних прав і свобод згідно зі ст. 49 Конституції, що не допускається відповідно до ч. 3 ст. 22 Конституції при ухваленні нових законів або внесення змін до чинних законів. Такі обставини дають підстави для неефективного забезпечення конституційних соціальних гарантій прав і свобод людини і громадянина у сферах життедіяльності людини. 


\section{Теорія, історія держави і права, конституційне право}

Так як Україною ратифіковані такі міжнародні договори, як Конвенції про захист прав людини i основоположних свобод (далі- Конвенція), Загальна декларація прав людини , то слід звернутися до положень, які закріплюють право на охорону здоров'я в цих документах, та визначити відповідність європейським стандартам конституційних гарантій в Україні. У цьому аспекті слід зазначити, що Конвенцією не передбачено безпосередньо захист соціально-економічних прав, у тому числі право на охорону здоров'я, але можливим є звернення за захистом цього права у розрізі низки інших статей Конвенції. Так, у практиці Европейського суду із захисту прав людини (даліEСП $\lambda$ ) виокремлюють порушення права на: життя (ст. 2 Конвенції), заборону тортур (ст. 3), права на свободу та особисту недоторканність (ст. 5), права на справедливий судовий розгляд (ст. 6), права на повагу до особистого і сімейного життя, на недоторканність житла (ст. 8). Виходячи 3 аналізу практики ЕСП $А$, можна зробити висновок, що право на охорону здоров'я має комплексний характер та включає право на інформацію та конфіденційність інформації про стан здоров'я; право на медико-соціальну допомогу; право на згоду на лікування та медичне втручання; право на сприятливе екологічне середовище, яке впливає на стан здоров'я та ін. Европейський досвід дає розуміння поняття права на охорону здоров'я як невід'ємної складової права на життя, яке захищається ст. 2 Конвенції, бо реалізація цього прав не можлива без реалізації права на здоров'я, так як нормальне біологічне та соціальне функціонування людини не можливе без здоров'я.

Аналізуючи рішення ЕСП у справах «Калашников проти Російської Федерації», «Биржиковський проти Польщі», «Д. проти Сполученого Королівства», «Попов проти Російської Федерації», слід зазначити, що порушення ст. 2 Конвенції вважається не лише у випадках позбавлення життя, а і при серйозних пошкодженнях організму людини, які не спричинили його смерть, але представляли серйозну загрозу його життю. Також в аспекті реалізації права на здоров'я є забезпечення своєчасної адекватної і необ- хідної медичної допомоги, яке передбачене ст. 3 Конвенції, та обов'язок держави забезпечити таку допомогу. Однак, у ряді рішень таких, як «Панайтеску проти Румунії», «Оял проти Туреччини», «Н. проти Сполученого Королівства», « Йо-Екале Мван'є проти Бельгіі» $\mathrm{ECП \curlywedge} \mathrm{зазначав} \mathrm{той} \mathrm{факт,} \mathrm{що} \mathrm{Кон-}$ венція не гарантує соціально-економічні права, включаючи право на безкоштовну медичну допомогу, і що скарги щодо якості медичної допомоги не є предметом спору відповідно до положень Конвенції або Протоколів до неї. Але варто зазначити, якщо таке право гарантовано законом держави, то буде порушення ст. 2 Конвенції, як, наприклад, було у справі «Панайтеску проти Румунії».

Не менш важливою соціально-економічною гарантією $є$ забезпечення захисту права на працю, яке закріплене в ст. 43 Конституції, що передбачає право кожного на працю та включає можливість заробляти собі на життя, яку особа вільно обирає або на яку вільно погоджується, крім того, зміст поняття права на працю включає відповідні гарантії реалізації цього права. Так, згідно 3 рішенням КСУ у справі за конституційною скаргою Жабо Тетяни Максимівни щодо відповідності Конституції України (конституційності) положень частини третьої статті 40 Кодексу законів про працю України від 4 вересня 2019 року, вільний вибір передбачає різноманітність умов праці, проте сталими (обов'язковими) є гарантії захисту працівника від незаконного звільнення за будь-яких умов праці, що є соціальним захистом держави, що також передбачає забезпечення реалізації конституційного права на відпочинок, закріпленого в ст. 45 Конституції [10]. Варто зауважити, що згідно $з$ приписами Конституції незалежно від підстав виникнення трудових правовідносин держава зобов'язана створювати ефективні організаційно-правові механізми для реалізації трудових правовідносин на рівні закону, а відсутність таких механізмів нівелює сутність конституційних прав і свобод працівника. У цьому аспекті слід зазначити практику ССП $\Lambda$ у справі «Eweida and Others v. The United Kingdom», у якому Суд визнавав звільнення і відсторонення працівників 
такими діями, що суперечать Конвенції [11], також Суд у справі «Олександр Волков проти України» висловив свою позицію щодо впливу на приватне та професійне життя обмежень, які накладені на доступ до професії та звільнень, які підпадають під дію ст. 8 Конвенції.

Таке закріплення гарантії кожного мати право на працю відповідає міжнародним стандартам у сфері захисту прав і свобод людей. А саме, стаття 23 Загальної декларації прав людини 1948 р. встановлює, що кожна людина має право на працю, на вільний вибір роботи, на справедливі та сприятливі умови праці й на захист від безробіття [12], поняття вільного вибору праці та вільного погодження на працю відповідає положенням ст. 4 Конвенції «Про захист прав людини і основоположних свобод» 1950 р., яка забороняє рабство й примусову працю, зокрема, ніхто не може бути присилуваний виконувати примусову чи обов'язкову працю [13].

Проте, варто зазначити, що право на працю різниться його нормативною фіксацією в зарубіжних державах. Так, наприклад країни 3 розвиненою демократією, СШІА, Канада, Данія, приділяють мало уваги закріпленню цього права в конституціях чи зовсім не приділяють, оскільки це право вважається невід'ємним і посягання на нього є неможливим. Натомість, у країнах колишнього соціалістичного табору, зокрема у Польщі, Угорщині, Білорусі конституційне право людини на працю закріплюється досить широко, зі встановленням цілої системи юридичних гарантій щодо рівності прав чоловіків і жінок, вільного вибору професії й роботи та ін. Однак, у конституціях зарубіжних країн право на працю сформульовано декларативно, але в деяких зазначається обов'язок держави реалізувати та гарантувати це право. Про це свідчить Конституція Італії, у якій у ст. 4 закріплено, що «за всіма громадянами визнається право на працю та створення умов, які забезпечують реальність цього права», а кожний громадянин «зобов'язаний здійснювати діяльність або функцію, що сприяють матеріальному або духовному прогресу суспільства», стаття 22 Конституції Греції зазначає, що держава турбується про створення умов для забезпечення повної зайнятості всіх громадян. Аналогічна норма міститься у Конституції Болгарії (ст. 48), Нідерландів (п. 1 ст. 19) [14].

Як підтверджує зарубіжний досвід, ефективну реалізацію конституційних гарантій прав і свобод людини і громадянина забезпечують юридичні гарантії. Юридичні гарантії полягають у закріпленні в законодавстві засобів, які безпосередньо забезпечують правомірну реалізацію, охорону й захист прав [9]. А саме, право на судовий захист - це гарантія здійснення прав і свобод, що існує у всіх демократичних державах, право на відшкодування матеріального та морального збитку, право на знання кожним свої прав і обов'язків, а також право на юридичну допомогу. Але насамперед найголовнішою юридичною гарантією $є$ принцип неприпустимості обмеження прав і свобод людини і громадянина без відповідної вказівки про це в законі.

Так, наприклад, у ст.17 Конституції Іспанії вказано: «Кожен затриманий повинен негайно і в зрозумілій формі бути проінформованим про його права та підстави затримання»; у ст. 37 Конституції Японії вказано: «За будь-яких обставин обвинувачений у кримінальній справі може звернутися за допомогою до кваліфікованого адвоката. У випадку, коли обвинувачений не в змозі зробити це сам, адвокат призначається державою» [15].

Відповідно до міжнародних стандартів, ч. 2 ст. 55 Конституції України закріплює, що кожному гарантується право на оскарження в суді рішень, дій чи бездіяльності органів державної влади, органів місцевого самоврядування, посадових і службових осіб [5]. Статтею 42 Закону України "Про Конституційний Суд України” закріплено право громадянина України, іноземця, особи без громадянства та юридичні особи на звернення до Конституційного Суду України 3 метою захисту своїх порушених прав. Формою реалізації зазначеного права $є$ конституційне звернення - письмове клопотання до Конституційного Суду України про необхідність офіційного тлумачення Конституції України та законів України з метою забезпечення реалізації чи захисту конституцій- 


\section{Теорія, історія держави і права, конституційне право}

них прав та свобод людини і громадянина, а також прав юридичної особи [16].

Також у європейських країнах має позитивний досвід запроваджений інститут омбудсмана (Уповноваженого 3 прав людини), цей інститут $є$ універсальним інструментом виявлення і сприяння усуненню порушень прав і свобод людини і громадянина. Тож новацією у державно-правовій системі захисту прав і свобод людини у нашій країні $є$ запровадження спеціального інституту Уповноваженого Верховної Ради України 3 прав людини. У Конституції України закріплюється право особи звертатися за захистом своїх прав до Уповноваженого (ст.55) і визначається, що через нього здійснюється парламентський контроль за додержанням конституційних прав і свобод людини і громадянина (ст.101). Статус, функції та компетенція Уповноваженого Верховної Ради України з прав людини закріплені у конституційному Законі України “Про Уповноваженого Верховної Ради України з прав людини", прийнятому Верховною Радою України 23 грудня 1997р.

Однак, саме проблема реалізації забезпечення юридичних гранатній впливає на захист конституційних гарантій прав і свобод людини і громадянина в Україні, яка полягає в ефективності діяльності судових гарантій, а саме, виконання судових рішень. Про що свідчить рішення ЄСПЛ щодо справи «Юрій Миколайович Іванов проти України», у якому системі виконання Українською державою судових рішень у сфері прав людини була винесена вкрай негативна оцінка.

Сучасна судова практика $\mathrm{ECП} \lambda$ має велике значення для судової системи в Україні так, як Конституцією України статтею 9 визначено, що чинні міжнародні договори, згода на обов'язковість яких надана Верховною Радою України, є частиною національного законодавства. Европейська Конвенція з прав людини була ратифікована Україною 17.07.1997 року (N 475/97-BP) та набула чинності для України 11.09.1997 року. Таким чином, Конвенція стала частиною національного законодавства і підлягає застосуванню.

\section{Висновки і пропозиції}

Право.ua № 4, 2021
Отже, проаналізувавши чинне законодавство, можна стверджувати, що в Україні закріплені основні конституційні гарантії прав і свобод людини і громадянина, які відповідають міжнародним стандартам зарубіжних країн, задля ефективного забезпечення захисту реалізації зазначених прав. Проте, з огляду судової практики вбачаються прогалини якісної та ефективної реалізації зазначених гарантій, що призводить до порушення та обмеження конституційних прав і свобод людини і громадянина. А саме, забезпечення юридичних гарантій у виконанні судових рішень, тому для вирішення проблеми реалізації конституційних гарантій необхідно вдосконалювати судову систему країни та проводити реформу, яка буде спрямована на вирішення питання щодо своєчасного та ефективного виконання рішень міжнародних та українських судів.

\section{入ітература}

1. John Locke Two Treatses of Government» https//ww.britannica.com/ biography/John-Lockt efтo2433 Цитака за виданням Локк Дж Сочинения: В 3т.-Т.3. М.: Мысль, 1988. сс. 137-405. (рос.)

2. Загальна теорія держави і права : підруч. для студ. юрид. вищ. навч. закл. /М. В. Цвік, О. В. Петришин, А. В. Авраменко та ін. ; за ред. д-ра юрид. наук, проф., акад. АПрН України М. В. Цвіка, д-ра юрид. наук, проф., акад. АПрН України О. В. Петришина. - Х., 2009. - С. 456

3. Смоленский М. Б., Мархгейм М. В. Конституционное право Российской Федерации: [учебник] / М. Б. Смоленский, М. В. Мархгейм. - Ростов н/Д: Феникс, 2009. $-446 \mathrm{c}$

4. Конституционное право: Учеб. для студентов юридических вузов и факультетов / Отв. ред. проф. В. В. Аазарев. - М.: Изд-во БЕК, 1998. - 430 с

5. Конституція України URL: https:// zakon.rada.gov.ua/laws/show/254\%D0\%BA/96$\% \mathrm{D} 0 \% \mathrm{~B} 2 \% \mathrm{D} 1 \% 80$

6. Закон України Про правовий режим надзвичайного стану, https://zakon.rada.gov. ua/laws/show/1550-14\#Text

7. Рішення Конституційного Суду України у справі за конституційним подан- 
ням 53 народних депутатів України щодо офіційного тлумачення положення частини третьої статті 49 Конституції України «у державних і комунальних закладах охорони здоров’я медична допомога надається безоплатно» (справа про безоплатну медичну допомогу). URL: https://zakon.rada.gov.ua/ laws/show/v010p710-02\#Text

8. Закон України Основи законодавства України про охорону здоров'я. URL: https://zakon.rada.gov.ua/laws/show/280112\#Text

9. Проект Закону про державні фінансові гарантії надання медичних послуг та лікарських засобів. URL: http://w1.cl.rada.gov. ua/pls/zweb2/webproc4 1?pf3511=61566

10. Рішення Другого сенату Конституційного Суду України у справі за конституційною скаргою Жабо Тетяни Максимівни щодо відповідності Конституції України (конституційності) положень частини третьої статті 40 Кодексу законів про працю України. URL: https://zakon.rada.gov.ua/laws/ show/va06p710-19\#Text

11. Case of Eweida and Others v. The United Kingdom. ECHR. Strasbourg. 25/05/2013. URL: https:/hudoc.echr.coe. int/fre-press \# \{\%22ite $\quad$ mid\%22:[\%22001115881\%22]\} (Last accessed: 05.05.2021)]

12. Загальна декларація прав людини. Резолюція Генеральної Асамблеї ООН.№ 217 від 10.12.1948 p. URL: https://zakon. rada.gov.ua/laws/ show/995_015\#Text (дата звернення: 01.16.2020).

SUMMARY
Constitutional guarantees of human
and civil rights and freedoms are of great
importance in the implementation of the policy
of a democratic country. The article examines
the basic constitutional guarantees. Compliance
of guarantees established in Ukraine with
international standards. An analysis of ensuring
the effective implementation of these guarantees
in Ukraine. The main gaps in ensuring the
implementation of the guarantee have been
identified. Ways and mechanisms of improvement
of the Ukrainian legislation for the decision
of a problem of realization of constitutional
guarantees are offered.

13. Конвенція про захист прав людини i основоположних свобод. Рада Европи. 04.11.1950 р. Урядовий кур'єр. 2010. № 215. URL: https://zakon. rada.gov.ua/ laws/show/995_004\#Text (дата звернення: 22.05.2021).

14. Конституції зарубіжних країн : навч. посіб. / авт.-упоряд. В. О. Серьогін,Ю. М. Коломієць, О. В. Марцеляк [та ін.] ; ред. В. О. Серьогін. Харків : ФІНН, 2009. $664 \mathrm{c}$.

15. Хромей В. В. Конституційне право на працю : монографія. Київ: Нац. торг.екон. ун-т, 2018. 240 с

16. Закон України Про Конституційний Суд України, https://zakon.rada.gov.ua/laws/ show/2136-19\#Text 